MONITORING SALURAN AIR ARTIFISIAL DI KAWASAN HUTAN GAMBUT MENGGUNAKAN METODE GEOBIA (GEOGRAPHIC OBJECT-BASED IMAGE ANALYSIS) YANG DISEDERHANAKAN: STUDI KASUS DI HUTAN SEBUBUS, KALIMANTAN BARAT

\title{
MONITORING ARTIFICIAL WATERWAYS IN PEAT FOREST AREAS USING GEOBIA (GEOGRAPHIC OBJECT-BASED IMAGE ANALYSIS) METHOD: CASE STUDY IN SEBUBUS FOREST, WEST KALIMANTAN
}

\author{
Muriadi and Wanglin Yan \\ Graduate School of Media and Governance, Keio University, \\ Shonan Fujisawa Campus, Japan. \\ E-mail: muriadii.a7@keio.jp
}

Naskah diterima: 27 Desember 2018; revisi terakhir: 28 Februari 2019; disetujui: 28 Maret 2019

How to Cite: Muradi and Yan, Wanglin. (2019). Monitoring Artificial Waterways in Peat Forest Areas Using Geobia (Geographic Object-Based Image Analysis) Method: Case Study in Sebubus Forest, West Kalimantan. Jurnal Borneo Administrator, 15 (1), 99-116. https://doi.org/https://doi.org/10.24258/jba.v15i1.420

\begin{abstract}
This paper presents a workflow capitalizing Google Earth's High-resolution Imagery (GEHRI) to detect and monitor Artificial Waterway $(A W)$ in a tropical peat forest. The workflow applies an Object-Based approach derived from concepts and techniques for indexing visual semantics in a ten-levels of visual structures. Three sequential stages are proposed as simplification of complex various object-based analysis. First stage, the ground characteristics of $A W$ were summarized based on ground observations and local knowledge. Second stage, object-based semantics were predicted using the summarized characteristics and on-screen digitization was conducted. In the third stage, the data were transferred and analyzed using a GIS application. A case study was conducted in Sebubus Forest of West Kalimantan Province, Indonesia. Seven images of GEHRI were found for the study area. From the analysis, it was found that since 2009 until 2017, artificial waterways had entered deep into the peat forest area. There were 66 objects allegedly as artificial waterways reaching $166.5 \mathrm{~km}$ in length which from the pattern was thought to be a part of the farming of local people. This study concluded that improvement of conservation in peat forest management and detection model and monitoring by using simplified object basis approach. It is conducted to strengthen monitoring peatland in a participatory manner where highskilled labor is not necessary.
\end{abstract}

Keywords: Artificial Waterway, Tropical Peat, GEHRI, GEOBIA. 


\begin{abstract}
Abstrak
Penelitian ini menampilkan model pendeteksian dan monitoring perkembangan saluran air buatan di kawasan hutan gambut tropis dengan memanfaatkan citra satelit resolusi tinggi dari Google Earth (GEHRI). Pendekatan yang digunakan adalah analisis citra berbasis objek yang diilhami dari konsep dan teknik pengindeksan Visual Semantic berdasarkan sepuluh tingkat visual struktur. Dalam penelitian ini, tiga tahap proses dirumuskan sebagai penyederhanaan berbagai proses analisis berbasis objek yang biasanya sangat rumit. Tahap pertama, ikhtisar karakter objek dilapangan dengan metode observasi dan survey lapangan. Tahap kedua, identifikasi semantik objek dan digitalisasi pada tingkat citra, dan tahap yang ketiga adalah analisis menggunakan aplikasi GIS. Penelitian ini menggunakan studi kasus yang dilakukan di kawasan Hutan Gambut Sebubus di Kabupaten Sambas, Kalimantan Barat, dan ditemukan tujuh citra dari GEHRI yang digunakan sebagai kawasan studi. Dari hasil analisis didapati bahwa sejak 2009 sampai dengan 2017, saluran air buatan telah masuk jauh kedalam kawasan hutan gambut. Terdapat 66 objek yang diduga kuat sebagai saluran air buatan dengan panjang mencapai $166,5 \mathrm{~km}$, yang dari polanya diduga bagian dari pertanian masyarakat lokal. Studi ini menyimpulkan bahwa diperlukan perbaikan manajemen konservasi kawasan hutan gambut dan model deteksi dan monitoring dengan menggunakan pendekatan berbasis objek yang disederhanakan. Hal ini dilakukan untuk memperkuat monitoring kawasan gambut secara partisipatif, dimana tenaga dengan keahlian tinggi tidak terlalu diperlukan.
\end{abstract}

Kata Kunci: Saluran Air Buatan, Hutan Gambut, GEHRI, GEOBIA

\title{
A. INTRODUCTION
}

In Indonesia, Geographic Object-based Image Analysis (GEOBIA) can be one of key tools for a future successful conservation and preservation management of tropical peat forest such as in the monitoring of the development of AWs in a preserved tropical peat forest, because it makes the effort easier and cheaper following the rapid development of technology in the acquiring high-resolution aerial imageries. However, it can only be happened if the method can be applied by proper users in the field. Current existing OBIA methods may still too complicated to be applied by the country's local government officers and grass root stake holders who involved in the peat forest conservation management.

Indonesia has the largest tropical peatlands in the world and acknowledged as globally significant tropical peatland ecosystems (Kristell Hergoualc'h et al., 2018). It is predicted around 14.91 million hectares tropical peatland spreading out in Indonesian islands such as Sumatera, Kalimantan, and Papua (Osaki \& Tsuji, 2016). Recently, the carbon-rich ecosystem becomes an international concern due to rapid degradation and repeated occurrences of huge wildfires resulted in the release of $\mathrm{CO} 2$ at worrying amount into the atmosphere. One activity that greatly increases the rate of degradation and loss of tropical peat forests in Indonesia is the construction of AWs (canals and ditches), whether they are legal or illegal, in and near the forests and peatlands (Jauhiainen, Limin, Silvennoinen, \& Yasander, 2016; Suryadiputra et al., 2005; Osaki \& Tsuji, 2016). Meanwhile, strategy such as canal blocking may not fully compensate the negative effects (H. Ritzema, Limin, Kusin, Jauhiainen, \& Wösten, 2014). Therefore, out of finding sustainable utilization techniques, monitoring the development of AWs is one of important factors for sustainability of the unique ecosystem.

In fact, exploitation of tropical peatland usually begins with the construction of any types of AWs. They are constructed in the tropical peatland to make the soil suitable for 
ture activities (Cooper et al., 2014; Evers, Yule, Padfield, O'Reilly, \& Varkkey, 2017; S.E. Page \& Baird, 2016; Rawlins \& Morris, 2010); for transporting forest products $\underline{(\mathrm{H}}$. Ritzema et al., 2014; Suryadiputra et al., 2005); and becomes complementary structure in the road construction, in which their residual soil is usually used for elevating the road construction.

Whatever the reasons behind the existence, AWs contribute hugely to the destabilization of the tropical peatland's water table (Osaki \& Tsuji, 2016). They drain tropical peat dome (Susan E Page et al., 2002) and change the nature of water flows which basically, owing to the convex character of tropical peat domes, flows in various directions as radial, widely spreadsheet flow rather than channel flow (H. Ritzema et al., 2014).

Currently, various efforts have been done to manage existing AWs in tropical peatlands, whether as part of sustainable agriculture activities or preservation actions (Padfield et al., 2014; H. P. Ritzema, Mutalib, Hassan, \& Moens, 1998). Canal-blocking system, for example, has been widely introduced to curb adverse impacts, particularly after huge wildfires in 2015. However, this system may not fully help. Some parts of peatland should be free from any open exploitation. In this case, monitoring the human-made structures can be another option for preserving the carbon-rich ecosystem. It is also needed for further assessment of any possible effects on people and the surrounding agricultural area. Yet, this kind of effort has been given little attention. On the other hand, monitoring of AWs development should be involving multi-stakeholders for effective preservation efforts. A simpler monitoring method capitalizing current familiar technology hopefully can increase the participation of all related stakeholders.

Remote sensing techniques can be very helpful for landscape monitoring purposes. However, often the techniques are still too advanced and costly for local governments and other stakeholders at community level. Therefore, a simple workflow of remote sensing approaches, such as of which uses open-geospatial data, incorporating local knowledge of the ground situation, and of which can be easily conducted by local governments' officials or other stakeholders, should be introduced. For example, in the monitoring of AWs in tropical peat forests, which are often very narrow, pixel based remote sensing may not appropriate. Besides, not all aerial imagery is appropriate for pixel-based analysis. With increasing High-Resolution Imagery such as of Google Earth, Object-Based Image Analysis (OBIA) should be better. However, the method can be too complicated for local government officials and grass roots stakeholders in tropical peat monitoring. Therefore, this research proposes such simplified method. Simplified GEOBIA (Geographic ObjectBased Image Analysis) can help local government officials and grassroot stake holders to capitalize increasing availability and quality of high-resolution aerial imagery for monitoring specific local objects important concerning their environmental landscape. GEOBIA is strongly associated with the notion of image segmentation but that is only one very typical geo-object-based delineation strategy (Blaschke et al., 2014). Many GEOBIA methods currently developed are focusing on automated segmentation and processes. Those techniques are likely too advanced for unskilled officials and stakeholders at community levels. On the other hand, plenty of existing useful local knowledge being ignored in most of developed GEOBIA. Therefore, incorporation of valuable local knowledge in the method is also important so that it can be really usable in the real implementation at the operational level. 


\section{B. RESEARCH METHOD}

GEOBIA is currently developing techniques in remote sensing. It is increasingly used following rapid advancement in satellite data resolution. This technique is getting attention because with the high-resolution imagery, pixel-based analysis is not appropriate to understand geographical object. In remote sensing or image analysis, it is known that as long as pixel sizes remained typically coarser than, or at the best, similar in size to the objects of interest, emphasis was placed on per-pixel analysis or even sub-pixel analysis for this conversion, but with increasing spatial resolutions alternative paths have been followed, aimed at deriving objects that are made up of several pixels (Blaschke, 2015).

However, GEOBIA currently lacks a systematic method to formalize the domain knowledge required for image object identification (Rajbhandari, Aryal, Osborn, Musk, \& Lucieer, 2017). This research proposes a simplified GEOBIA (Geographic Object-Based Image Analysis) capitalizing GEHRI to monitor the development of AWs in a preserved tropical peat forest. A workflow consists of three sequential stages is conducted. It is a simplification of various complex object-based analyses. In the workflow, firstly the ground characteristics of AWs are summarized based on ground observations and local knowledge. In the second stage, object-based semantics were predicted using the summarized characteristics. In the last stage, the data were transferred and analyzed using a GIS application. To test the workflow, a case study was conducted in Sebubus Forest of West Kalimantan Province, Indonesia.

1. The three sequential stages

Alejandro Jaimes and Shih-Fu Chang (Jaimes \& Chang, 2002) distinguished between the visual and non-visual content of an image. This distinction still becomes key foundation in current Object-Based Image Analysis (OBIA). The visual content of an image corresponds to what is directly perceived when the image is observed (the lines, shapes, colours, objects, and so on). The non-visual content corresponds to the information that is closely related to the image, but that is not present in the image.

What knowledge or information required for an OBIA according to them, can be understood from a ten-levels of visual structure. The structure depicts a relationship between Syntax (percept), Semantics (visual concept), and Knowledge. The key to this structure is, the required knowledge corresponds to each level of the structure. Current development of GEOBIA in general can be traced back to this structure.

In short, bringing this concept into a simple applicable technique, we propose three stages of processes, which are applied in this study. The stages for monitoring AWs in tropical peat forest are aimed at helping to capitalize current familiar technology for involving community's participation in managing the valuable ecosystem. The stages are:

a. The first stage is collection of required information related to the AW's general characteristics at ground level. At this stage, fieldworks and ground surveys were conducted. Some interviews with key informants consisting of local people and local government's officials are included at this stage. Some information such as general sizes and dimensions used as well as methods used by local people in constructing AWs are summarized. That information supposed to be the image of local knowledge on the subject. As aforementioned, the knowledge is required as semantics for detecting AW. It is also valuable reference to differentiate AW from Natural Waterway (NW), or any other artificial structures that may characteristically have similarity with AW. For example, roads and electricity cable networks are structures that possibly have similar visual semantics on images. 
b. After understanding the characteristics of AW on the ground, the next stage is aimed on understanding the characteristics of the objects at image level. Image analysis was carried out before on-screen visual digitization was conducted directly through the Google Earth Pro application. This software can be downloaded and installed freely. Fortunately, this application enables us to do on-screen digitization. This is very helpful for digitization of investigated objects into geo-database.

Digitization using GE produces files in KML (Keyhole Markup Language) format. It is a geographic information system format containing features such as images, lines, polygons, placemarks, 3D models, textual descriptions, etc. Those features are important for representing AW's properties under investigation. For simplification, in this case, lines are used to represent the AWs.

The other important thing in the process is to grid the area. The grid is important to solve scale bias during context finding. To find the context of an object we have to scroll zoom in and zoom out to see the object from different scales. The gridding can be easily made in a GIS application and then opened in GE.

On the other hand, there are four AW's properties that determine their capability to transport water. The properties are the length, width, depth, and slope. However, the length of AW is the main focus in this research. The length of an AW shows the network of the structure and its influence to draining an area. Therefore, in this study AWs are digitized as lines instead of polygons. However, if it is required, the depth and width of AWs can be added later into file's attribute, which is available in any GIS application, for further comprehensive analysis.

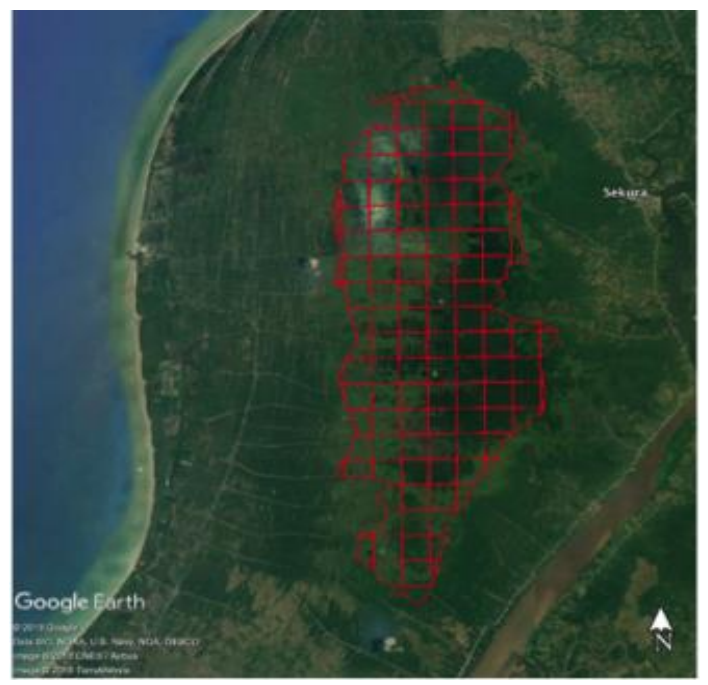

Figure 1

Sebubus Forest Area Gridded by $1 \mathrm{~km} /$ Block to Help the Process of Visual on-Screen Digitization

c. On the last stage, GIS application is used to analyse obtained geodatabase. While, a simple analysis such as measurement of a feature can also be done directly in GE application, a transfer into specific GIS application is needed for better analysis and further processes. GIS is a computerized system for the capture, storage, querying, analysis, and display of spatial data, and is used predominately by the government, private companies, and nongovernmental organizations (NGOs) across Indonesia 
(Bretz, 2017). Common file format for GIS analysis is Esri Shapefile (SHP). Using GIS application, various data manipulation, enhancement, and linkage can be done. It is also useful for conducting further social and behavioural analysis. The use of GIS in social and behavioural sciences is an increasingly essential component as a tool for acquiring and communicating geographic knowledge (Van Kreveld, 2017).

One of GIS application, which can be used for GIS analysis, is Quantum Geographic Information Systems (QGIS). It is an open source application that means any parties can simply download it from the Internet for full access to the application features. This application has several tools for GIS analysis.

There are various types of analysis can be done once the data have been transferred into a GIS application. However, in this paper, we give only two processes. The first is a mapping or visualization of spatial data. Mapping is important for analysing geographical position, distribution, direction, and extent of objects. Therefore, mapping or spatial data visualization is made to give a comprehensive picture of the AW development in the site. In this study, digitized AWs data are transferred from KML format into SHP format.

The second analysis is statistical analysis that is required to give a deeper understanding of the development of AW in the site. For example, to understand the spatial and temporal development of AW, a statistical summary is required. Questions such as, how long the AW has been developing over time? How many new AW systems exist in the area in specific time? All can be answered using statistical tools. In the QGIS application, this aim can be easily achieved since the application has been equipped with some simple statistical tools.

\section{Study Area}

Sebubus Forest is located in the northern part of West Kalimantan Province, Indonesia. It lies near the coastal line of Sambas Regency. It is a tropical peat forest with a depth of its peat dome predicted more than 6 meters (Balitbang Pertanian, 2011). Therefore, it is one of the valuable tropical peat ecosystems; despite the size is just less than 15.000 hectares.

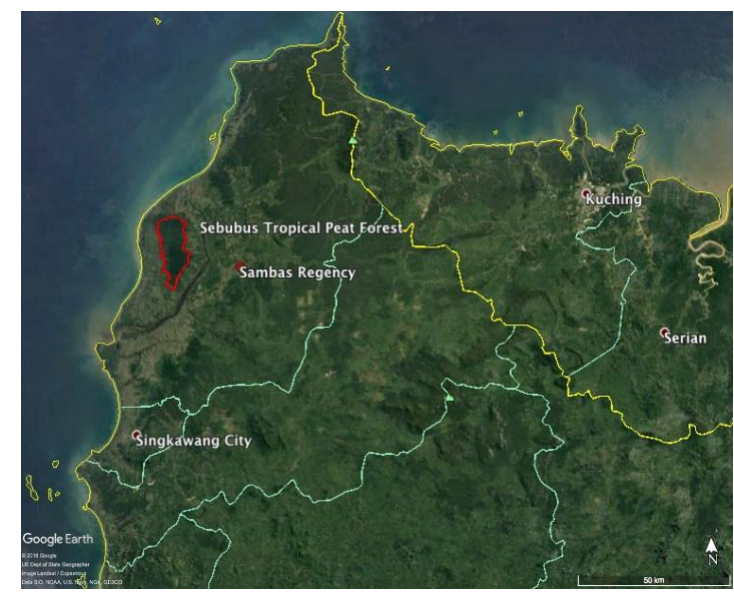

Figure 2.

Sebubus Forest Viewed from the Google Earth

The forest lies between two main water systems. On its west side is Natuna Sea. While on the eastern part, big Sambas River flows along its side. The forest completely surrounded by local communities and therefore agriculture lands such as paddy fields and other plantations can be found along its sides (see Figure 3). In fact, the forest plays a very 
Muriadi and Wanglin Yan

important role for the communities and their agriculture activities since the tropical peat forest is the main and the only freshwater holder for the surrounding area. Simply, the forest determines the ecological balance of the area. It encompasses 21 villages within four sub-districts.

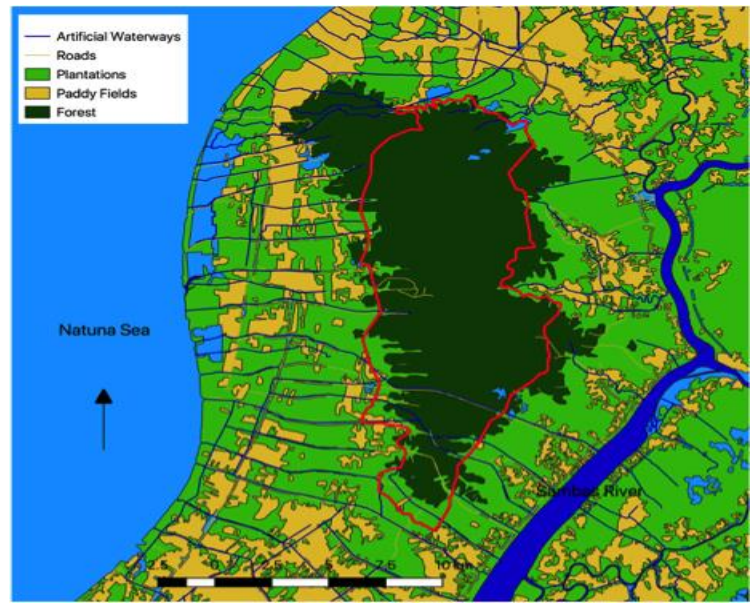

Figure 3.

Sebubus forest and Its Surrounding Agriculture Area Based on Local Government's Geodatabase

Sebubus Forest has been enacted by law as production forest (protected) at least since 1982 (Ministry of Forestry, 2014). According to the law, only limited forestry products can be harvested from the forest. Open exploitation is basically prohibited. However, the ecosystem, which basically for a long time becomes solely fresh water holder for its surrounding agriculture activities, ironically has been experiencing pressures from its surrounding agricultural activities. Accessibility to the area is very poor. To clarify the real situation by going deep into the forest is something hard to do.

\section{CONCEPTUAL FRAMEWORK}

\section{Importance of Artificial Waterways Monitoring for Tropical Peat Forest Conservation}

Conserving peatland on a landscape scale, with their hydrology intact, is of international conservation importance to preserve their distinctive biodiversity and ecosystems services and maintain their resilience to further environmental change (Roucoux et al., 2017). In fact, conserving peatland's hydrology intact is the most important thing. Currently, drainage is the most dangerous driver for tropical peatlands. Not only it stops the formation of peat by eliminating water as the main component in the mire formation, but also it is prerequisite for logging and agriculture activities. In addition, it makes the organic soil of peatland area vulnerable to wild fires. Drainage, along with deforestation and fires, are the main drivers behind the rapid degradation of tropical peatlands since last two decades. Those all resulted in change of hydrological conditions, typically groundwater level, and accelerate oxidative peat decomposition (Hirano, Kusin, Limin, \& Osaki, 2015). These drivers are compounded by a complex mix of indirect socioeconomic, policy and climate change-related factors (Dohong, Aziz, \& Dargusch, $\underline{2017)}$. 
One example of how devastating artificial waterways to the tropical peatlands is MRP (Mega Rice Project). In the 1990s the Government of Indonesia decided to develop one million hectares of peatlands for agriculture in Central Kalimantan on the Island of Borneo by constructing thousands of kilometres of canals resulted in over-drainage $(\mathrm{H}$. Ritzema et al., 2014). In consequence, many wild fires occurred and caused irreversible damage to the overall peatlands ecosystem (Ishii et al., 2015). Restoration of degraded peatlands normally starts with restoring the water table to rewet the surface in order to control fire and to initiate reforestation. Canal blocking strategies are a potential means for accomplishing this. (Ritzema et al., 2014). However, whether a sustainable utilization of the tropical peatland through specific artificial waterway's management can be achieved has been questioned. Many scientists believe that current normally practiced management is not sustainable for tropical peatland agriculture (Wijedasa et al., 2017). More peat scientists argue that the actual debate should be focused no longer on how to develop drainage-based agriculture, but on whether the sustainable conversion to drainage-based systems is possible at all (Evers et al., 2017). In this sense, the narrative, which becomes the basis for the exploitation of tropical peatland in Indonesia that sustainable peatland's utilization can be achieved by using drainage-based agriculture practices, should be changed. Until new evidence say otherwise, sustainable peatland utilization should be confined in the narrative of preserving the pristine peat forest ecosystem. Therefore, monitoring the development of the AWs (drainages, irrigation, canals, etc.) is far more important, whether for prevention purposes as well as for impact assessment measures.

In Indonesia, the government of the country has trying hard to cope with the extreme pressures experienced by the tropical peat forests all over the country (Agus, Mulyani, Nurida, Ariani, \& Widiastuti, 2017). The country has launched several regulations for improving peat sustainability, including the suspension of new permits for peatland utilization and the formation of Peat Restoration Agency, mandated for restoring degraded peatland (Agus et al., 2017). However, misguided land use policies have resulted in widespread peatland degradation during the past 20 years (Dohong et al., 2017). In fact, deforestation of the tropical peat forests has given some severe consequences. Repeating occurrences of huge forest fires for example, resulted in regional scale smoke haze disasters. A study by Harvard Columbia University estimated that smoke haze from tropical peat fires mostly in Indonesia linked to more than 100.000 death in SeptemberOctober 2006 (Koplitz et al., 2016). Another study indicated that peat fires mostly from Sumatra of Indonesia in June 2013 caused air condition in Singapore reach an all-time record high that made the air of the country very unhealthy (Gaveau et al., 2014). Those are only small examples of consequences to be paid for a failed tropical peat forests management and conservation.

\section{GEHRI and Object-Based Image Analysis for Landscape Monitoring.}

The applications of Object-Based Image Analysis (OBIA) in remote sensing studies of wetlands/peatlands have been growing over recent decades, addressing tasks from detection and delineation of wetland/peatland bodies to comprehensive analy ses of withinwetland cover types and their change (Dronova, 2015). OBIA methods were driven by the need to more accurately map multi-scaled Earth features with high-spatial-resolution imagery (HSRI) such as tree, the building, and the field (Blaschke, 2015).

Google Earth, released in 2005, is a satellite imagery-based mapping software widely used in various fields. It has HSRI for some areas on earth. The image can be less than 1meter resolution. It makes the application becomes a valuable source in landscape 
monitoring such as of the development of AW in tropical peatlands. Moreover, the free software also has multi-temporal capability, which is another advantage to monitor natural resources. However, it has also some limitations. One of them is that it may not be possible to obtain the original multispectral band data. That means it is not possible to get the actual pixel numbers or the brightness/reflectance values and hence image classification using unsupervised or supervised techniques cannot be carried out (Malarvizhi, Kumar, \& Porchelvan, 2016). In other words, the pixel-based analysis may hardly be conducted using GEHRI as data.

In fact, HSRI is not really suitable for pixel-based analysis. In remote sensing or image analysis, it is known that as long as pixel sizes remained typically coarser than, or at the best, similar in size to the objects of interest, emphasis was placed on per-pixel analysis or even sub-pixel analysis for this conversion, but with increasing spatial resolutions alternative paths have been followed, aimed at deriving objects that are made up of several pixels (Blaschke, 2015). In geographical domain, this technique is called GEOBIA (Geographic Object-Based Image Analysis). It is a growing remote sensing technique in remote sensing analysis (Blaschke et al., 2014). In the process, instead of uses individual pixels, this technique analyses objects from segmentation. It means objects are classified using color, shape, size, texture, and context. Therefore, the GEOBIA can make full use of the spectral, texture, geometry and other characteristics of GEHRI, which is supposed to compensate the limitation of poor spectral characteristics of the images $\underline{\mathrm{Hu} \text { et }}$ $\underline{\text { al., 2013). }}$.

\section{Previous Researches and Key Differences}

There are some previous researches applying GEOBIA in the wetland/peatland area. A review by Dronova (2015) presents a synthesis of 73 studies in regarding wetland/peatland that applied OBIA to different types of remote sensing data, spatial scale and research objectives. She found that based on their objectives the researches could be grouped into five groups, 1) Detection \& delineation: studies detecting the presence and/or delineating their boundaries in landscapes with significant proportion of nonwetland/peatland natural and anthropogenic land cover; 2) Typological classification of delineated wetland units: assignment of mapped wetland bodies into hydrological, geomorphological and ecological categories without detailed mapping of withinwetland/peatland cover; 3) Classification of within-wetland cover types and/or vegetation: mapping within-wetland surface composition and vegetation types, sometimes targeting specific classes such as invasive plant species; 4) Analysis of wetland/peatland's change over a particular period of time; and 5) Analysis of within-wetland biophysical and ecological properties using OBIA outcomes for subsequent ecological study: wildlife habitat analyses, spatial modelling of ecosystem properties such as carbon stocks, net primary productivity, wetland/peatland geomorphology and vegetation structure, and analyses of disturbance.

This study is basically in the fifth group. Key differences to previous ones however, are on the technique level. While previous researches mostly merely focus on image characteristics, this research goes into ground level to develop a knowledge foundation before going into image semantic analysis. This study also different in term of its use on monitoring AW as the focus, that is less studied previously.

At its most fundamental level, OBIA requires image segmentation, attribution, classification, and the ability to query and link individual objects (aka segments) in space and time (Blaschke, 2015). Segmentation is viewed as key factor for successful analysis. In 
previous researches reviewed by Dronova (2015), segmentation outputs are often controlled by parameters that constrain within-object spectral variation, or heterogeneity, as well as other method-specific criteria. To do so, specific application and data, which is usually expensive, is needed and at least intermediate remote sensing skill is required. Meanwhile, GEHRI is free software and easily used, but images or series of images may come from different sensors. Therefore, characteristics of the images may vary depend on how the sensors interact with ground objects. Understanding the ground objects in this sense becomes important to understand the image semantics.

Currently, there are several software packages for GEOBIA, such as Erdas Objective, ENVI EX, IDRISI, etc. Better application to be used depends on many aspects. Skill, available resources, and study purposes determine which application is better choice. However, in this research, we prefer to maximize the use of GEP, not only for simplification but also to optimize the advantage of free popular applications. On the other hand, HSRI is the current easiest way to obtain remote sensing data. This data can be obtained using a small drone or even simpler is, by using an open geospatial database available from the Internet such as of the GEHRI. Using HSRI, we can see details of many objects on the ground. Hence, the human visual capability can be used to conduct image analysis. As a human being, we are a very good image analyst. We can extract higher-level image features. As we know, the human visual cortex is an excellent image analysis apparatus, human visual perception model is a basic inspiration of many image analysis tools such as edge detector, or neural network (Khodaskar \& Ladhake, 2015). Simply, combining human visual capabilities and existing ground knowledge to analyse GEHRI using GEOBIA approaches supposed to be a good option for monitoring AWs in tropical peatlands.

\section{RESULT AND DISCUSSION}

\section{a. Results of stage 1}

Table 1 summarizes information collected from fieldworks and ground surveys. It is found that in general, AWs in the area can be divided into three topologies. Those are the primary, the secondary, and the tertiary. While the way people construct AWs can be categorized into the traditional way and modern way. Primary AW, which is used for drainage of tropical peatland dome, flows water from peat dome into big rivers or sea. It is also used as the main transportation networks for accessing the area. Secondary AW is also used for drainage but mostly used to expand the reach of primary AW to a larger area. Meanwhile, tertiary AW is used to drain land lots and also used as territorial delineation (border).

Table 1.

Generalized Ground Characteristics of Artificial Waterways in Peatland Areas in Sambas Regency

\begin{tabular}{lll}
\hline Typology & \multicolumn{1}{c}{ Traditional } & \multicolumn{1}{c}{ Modern } \\
\hline Primary & Width: $1,5-2 \mathrm{~m}$ & Width: $2-4 \mathrm{~m}$ \\
& Depth: $1-2 \mathrm{~m}$ & Depth: $2-3 \mathrm{~m}$ \\
& Construction Method: & Method: Heavy equipment \\
manual/traditional & Direction: from peat dome to sea or main \\
& Direction: from peat dome to sea or & rivers \\
& main rivers & Purpose: drain peat dome and collect water \\
& Purpose: drain peat dome and & from secondaries and tertiaries \\
& collect water from secondaries and & Other:
\end{tabular}




\begin{tabular}{|c|c|c|}
\hline & tertiaries & - $\quad$ parallel to the main road \\
\hline & Other: & - $\quad$ the residual soil is stacked to \\
\hline & - $\quad$ parallel to the main road & elevate road (2-6 m width) \\
\hline & - $\quad$ the residual soil is stacked & - $\quad$ the residual soil on one side stacked \\
\hline & to elevate road (1-3m width) & \\
\hline & - $\quad$ the residual soil both sides & \\
\hline & stacked & \\
\hline \multirow[t]{13}{*}{ Secondary } & Width: $60-1 \mathrm{~m}$ & Width: $1-2 \mathrm{~m}$ \\
\hline & Depth: $1-1,5 \mathrm{~m}$ & Depth: $1-1,5 \mathrm{~m}$ \\
\hline & Method: manual/traditional & Method: Heavy equipment \\
\hline & $\begin{array}{l}\text { Direction: from peat dome to sea or } \\
\text { main rivers or primary canals }\end{array}$ & $\begin{array}{l}\text { Direction: from peat dome to sea or main } \\
\text { rivers or primary canals }\end{array}$ \\
\hline & $\begin{array}{l}\text { Purpose: collect water from } \\
\text { tertiaries }\end{array}$ & $\begin{array}{l}\text { Purpose: drain peat dome and collect water } \\
\text { from secondary and tertiaries }\end{array}$ \\
\hline & Other: & \\
\hline & - $\quad$ Usually parallel with the & \\
\hline & main road but also sometimes & \\
\hline & parallel to secondary roads & \\
\hline & - $\quad$ the residual soil is stacked & \\
\hline & to elevate road (1-2 m width) & \\
\hline & - $\quad$ the residual soil is stacked & \\
\hline & one side & \\
\hline \multirow[t]{5}{*}{ Tertiary } & Width: $30-50 \mathrm{~cm}$ & \multirow[t]{5}{*}{$\mathrm{n} / \mathrm{a}$} \\
\hline & Depth: $30-70 \mathrm{~cm}$ & \\
\hline & Method: manual/traditional & \\
\hline & $\begin{array}{l}\text { Direction: from farmland to } \\
\text { secondary or primary canals }\end{array}$ & \\
\hline & $\begin{array}{l}\text { Purpose: control water of farmland } \\
\text { and as borderline }\end{array}$ & \\
\hline
\end{tabular}

On the other hand, three characteristics found to be appropriate to differentiate AW from natural waterways (NW). First, the width of the waterway's body in which AW always has a constant or regular width, contrary to NW's irregular one. Second, based on shape and turning tendency. AW tends to have straight shape with edged turns, while NW tends to swirl with curved turns. The third is related to the fact that AW in tropical peatland always parallels with the road. On the image (table 2), it can be seen that AW are always darker than the parallel road, both in color and grey image.

b. Results of stage 2

Digitization was conducted based on each available image for the site. There were seven images found for the Sebubus Forest. The images come from two sources: Digital Globe and CNES/Airbus. The images are in grey and colour.

Table 2.

Images Found from GE for the study site

\begin{tabular}{cccr}
\hline No & Date of Image & Original Source & Characteristics \\
\hline 1 & $2009-04-03$ & Digital globe & Grey \\
2 & $2011-03-27$ & Digital globe & Grey \\
3 & $2013-10-02$ & Digital globe & Colour \\
4 & $2014-08-31$ & CNES/Airbus & Colour \\
5 & $2015-07-23$ & CNES/Airbus & Colour \\
\hline
\end{tabular}




\begin{tabular}{lllr}
\hline 6 & $2015-09-08$ & Digital globe & Grey \\
7 & $2017-27-06$ & Digital globe & Colour \\
\hline
\end{tabular}

From the GEP, we found seven images correspond to the Sebubus Forest. We have digitized the images one by one to produce a geodatabase. The summary of the geodatabase can be seen from table 2. From the summary, it can be seen that a new image is not always available every year for a specific area. After 2009 for example, it required two years before a new image installed for the same area. It also happened after that. The next image found is for 2013. Meanwhile, in 2015 two images are found in the same area for the year. It means that irregularity characterizes image availability in the GEP. The irregularity seems happened to every area.

Despite the irregularity, table 3 suggests that the time-serial analysis for landscape changes like AW still probable to be conducted. Even though regular yearly changes cannot be traced back. Yet, the temporal analysis can be done and it is one of the advantages available on the application.

Table 3.

Results of Digitization from Analysed Images

\begin{tabular}{lcrlr}
\hline \multirow{2}{*}{ No } & Date of Image & $\begin{array}{c}\text { New } \\
\text { Detected AW }\end{array}$ & \multicolumn{1}{c}{ Description } & $\begin{array}{c}\text { Total Length } \\
(\mathrm{Km})\end{array}$ \\
\hline 1 & $2009-04-03$ & 22 & First detection & 35.62 \\
2 & $2011-03-27$ & 12 & 5 new, 7 continuation & 42.66 \\
3 & $2013-10-02$ & 10 & 5 new, 5 continuation & 25.97 \\
4 & $2014-08-31$ & 2 & 2 new & 8.14 \\
5 & $2015-07-23$ & 8 & 4 new, 4 continuation & 19.22 \\
6 & $2015-09-08$ & 5 & 4 new, 1 continuation & 7.23 \\
7 & $2017-27-06$ & 12 & 12 continuation & 25.99 \\
\hline
\end{tabular}

c. Results of stage 3

At the last stage, geodatabase obtained from on-screen digitization was transferred into QGIS and visualized into maps as depicted in figure 4. In the figure, results for the year 2015 are combined into one map so that only six maps are presented.

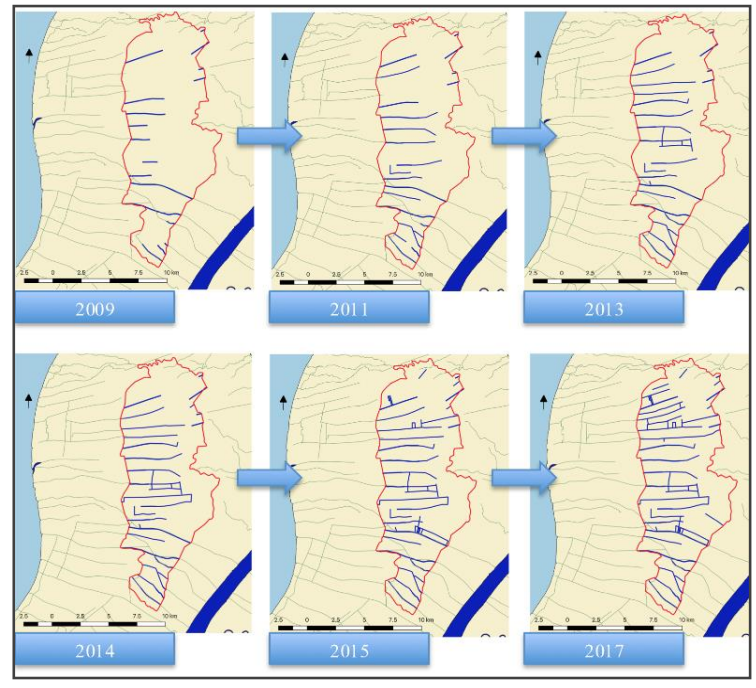

Figure 4.

Sequntial Maps of AWS'Development in Sebubus Forest from 2009 until 2017 
Meanwhile, a very simple statistical results tool from QGIS application is presented in table 4 . The summary shows a general statistic of the data. It shows that there are 66 objects identified as AWs from 2009 until 2017 with minimum length is around 260 meter and longest one is around $7.4 \mathrm{~km}$. In total from 2009 until 2017 there has been $166.5 \mathrm{~km}$ AWs in Sebubus Forest.

Table 4.

Statistical Results from QGIS Application

\begin{tabular}{llr}
\hline 1 & Analyzed field: & Length \\
2 & Count: & 66 \\
3 & Unique values: & 59 \\
4 & NULL (missing) values: & 0 \\
5 & Minimum value: & 0.26 \\
6 & Maximum value: & 7.69 \\
7 & Range: & 7.430000000000001 \\
8 & Sum: & 166.47999999999996 \\
9 & Mean value: & 2.522424242424242 \\
10 & Median value: & 2.04 \\
11 & Standard deviation: & 1.866699453667193 \\
12 & Coefficient of Variation: & 0.7400418305023713 \\
13 & Minority (rarest occurring value): & 0.26 \\
14 & Majority (most frequently occurring value): & 0.51 \\
15 & First quartile: & 0.77 \\
16 & Third quartile: & 3.62 \\
17 & Interquartile Range (IQR): & 2.85 \\
\hline
\end{tabular}

Based on the above results, there are at least three interesting points to be discussed. First, related to the trends and characteristics of AWs development in Sebubus Forest. Second, related to the use of GEHRI for monitoring of natural resources. And the third, related to the implication on tropical peatland management.

a. Trends and characteristics of AWs development in Sebubus Forest:

Based on its status as production forest (Ministry of Forestry, 2014), very limited activities allowed in the area (The President of Republic of Indonesia, 2016). Local people can, in a very limited way, harvesting forest products for their livelihood. The activities should not change the nature of the forest. Agricultural activities should be strictly prohibited. However, the results of this study show contrary condition. Despite in a limited extent only, some AWs have already existed in the forest since 2009. Hard to detect when actually the infiltration began, but there is a high tendency that AWs have been developing mostly from the western part of the forest.

Based on local government databases, there are several villages on the western part of the forest. By 2011, almost all villages in the western part showed new construction of AWs. Meanwhile, development from the eastern part remained stagnant. On average, there have been $20.81 \mathrm{~km}$ of new AWs developed in Sebubus Forest every year from 2009 until mid of 2017. Around 8 new systems were built every year with an average length of around $2.5 \mathrm{~km}$ each. That is a rapid development with steady increase year to year.

Until 2011, mostly only primary canals dominated the development. It can be seen from the direction of the lines that directly flow from central part of the forest to main 
water systems (Natuan Sea in the West and Sambas River in the East). By 2013, some secondary canals were developed. This indicates that the AWs have agricultural purposes. Secondary canals usually aimed at expansion of land occupation in the peatland (Vonk, 2011). Secondary canals are used to expand the occupancy area while opening access for more drainage systems.

In general, detected AWs in the forest indicate that they are the continuation of previously existing agriculture drainage systems in surrounding villages. It means that the utilization of the tropical peatland likely related to the increasing demand for new agriculture land site. The position from one waterway system to another varies from 500 to 1000 meters, which also shows that they are most likely for agriculture purposes. Based on an interview with officials of local agriculture department of Sambas Regency, commonly agriculture land site in Sambas Regency is around 40 to 50 meters wide and 500 meters long or 2 to 2.5 hectares each. On the other hand, the variation of distance from one system to another and the formation give a clue that mostly the AWs developed in the forest are of the local community's agriculture purpose. Since big plantation companies usually develop a very neat and uniformed design.

The development of AWs was still in the same tendency until 2014 in which primary canals developed deeper. They were crossing the peat dome area. However, tertiary canals were detected in 2015 and the primary canals were completely crossing the between two sides. By 2017, the AW networks totally covered the forest. A condition that is almost irreversible for the ecosystem health. At this stage, massive AW networks almost certainly capable to drain the whole water table of the peat forest in short period.

b. The implication on the use of GEHRI for landscape monitoring:

GE is an open access application increasingly popular and widely used for various purposes. It is a simple application with powerful capabilities. The high-resolution images in GE provide methodological development opportunities for various research and analysis approaches. Although the best image quality in GE is found mostly in highly populated areas and important landmarks (Harrington et al., 2017), this study found that its use for analysing unpopulated areas such as forests is still a great opportunity.

With an appropriate approach, GE is a simple way to obtain geodatabase. Its HRI is developing following advancement in satellite data technologies. It is opportunity for different fields. In natural conservation and preservation domain, researchers are developing methodological approaches for its use properly. More accurate and robust techniques are important. However, simple approaches are in some extent required and beneficial. As presented in the above results, a simplified approach gives very clear images of how AWs have been developed in a tropical peat forest. Two key points on the use are on understanding the object's characteristics at ground level and understanding objects semantics at image level as well as the characteristics of the images themselves.

Good understanding and enough information on characteristics of the object at ground level ease the process to identify the object on images. Existing knowledge and information at ground level can be an advantage for local stakeholders in the natural resource preservation and conservation efforts. Because local people usually have enough knowledge and information related to their landscape. In fact, many objects have very local characteristics. Unpaved roads in Kalimantan's tropical peatland, for example, are generally elevated higher than surrounding soil compared to unpaved roads in mineral soil in Java. 
On the other hand, despite being packed in one application, images on GEP have different characteristics for different locations. Because the images in the application are basically come from various original sources as we can see from Table 2. Therefore, understanding the characteristics of the images for a specific area is important for better object's classification.

c. The implication to the tropical peatland management

The implication of this work to the tropical peatland management can be seen from two perspectives. First, on the substance of the results in which AWs are detected infiltrating to the forest in an irreversible level, in spite of the fact that the forest is a preserved forest. The results show that the infiltration was just rapidly happened during the last decade. As presented before, local government data depicts that before 2009 the forest was relatively free from AW, particularly on its peat dome. However, during the last decade, the infiltration was so rapid that almost all parts of the forest have been exposed to AWs.

There are several indications that the local people are involved in the development. Why do people do such suicidal development is not part of this work to answer it. Anyhow, this is a challenge for the preservation of the tropical forest. At a glance, the results tell us that tropical peat forests surrounded by local communities seem to be vulnerable to traditional agriculture activities. In consequence, people around the ecosystem are very vulnerable to adverse impacts. While stakeholders may fail to recognize the vulnerability. The community may be impacted severely

This suggests that a new approach to tropical peatland management is required. Enacting law alone may not enough to preserve the forest even if it is very precious and may influence the lives of many. Law enforcement is also unlikely to be a sole solution because those involved in the development are communities in large number. Instead, a participative forest management may be better.

Second, on the perspective of tropical peatland monitoring methods, a simpler approach can help not only local governments to monitor protected tropical peat forest in their administrative area, but also helps other stakeholders such as Non-governmental Organizations (NGOs) and communities interested in natural resources protection and preservation. With the simplicity, the non-professional researcher can conduct appropriate analysis, at least to recognize problems that often hide in blurring socio-environmental issues.

\section{E. CONCLUSIONS}

Despite having been enacted as preserved forest, Sebubus forest has experienced massive open exploitation in the last decade. Patterns and trends of development of AWs in the forest indicate that demand for new agricultural land sites may behind the rapid penetration of AWs into the forest. This research does not going into deep analysis on the impact of the open exploitation to the people and surrounding agriculture activities. However, considering the importance of the forest to the surrounding agriculture and communities, the destruction of the forest may certainly sooner or later bring about severe consequences.

Results of this study also suggest that a new approach of tropical peatland preservation and management is needed. The ecosystem is very vulnerable to human pressures. It is often, recognizing the vulnerability is far from simple, and understanding its cause is even harder (Yan \& Galloway, 2017). Monitoring the ecosystem using the simple 
approach in which non-specialist researcher can do it should be developed. As presented in this paper, using simple workflow utilizing open geospatial data such as GEHRI, we can detect and monitor the development of human construction in the protected forest. The simplicity of the workflow enables almost everyone to do natural resources monitoring. Using free familiar applications and incorporating it with available local knowledge and information should be able to ease the involvement of stakeholders at the grassroots level. Meanwhile, using GEHRI with a simple process as presented in this study may not give a deep analysis. Yet it is enough to recognize a shadow of vulnerabilities, both on the natural resources and the communities.

\section{F. ACKNOWLEDGMENT}

We would like to thank the Office of Research Development and Sponsored Project at Keio University Shonan Fujisawa Campus for supporting us through this research. Fieldworks and research in this paper are funded by Taikichiro Mori Memorial Research Fund and Keio University Doctorate Student Grant-in-Aid Program 2017.

\section{REFERENCES}

Agus, F., Mulyani, A., Nurida, N. L., Ariani, R., \& Widiastuti, F. (2017). Peat soil carbon monitoring and management in Indonesia. GLOBAL SYMPOSIUM ON SOIL ORGANIC CARBON. Retrieved from http://www.worldagroforestry.org/output/lumens

Balitbang Pertanian, K. P. (2011). Peta Lahan Gambut Indonesia Skala 1:250.000. Jakarta: Balai Besar Penelitian dan Pengembangan Sumberdaya Lahan Pertanian.

Blaschke, T. (2015). Object Based Image Analysis: Evolution, History, State-of-the-Art and Future Vision, (April 2016).

Blaschke, T., Hay, G. J., Kelly, M., Lang, S., Hofmann, P., Addink, E., ... Tiede, D. (2014). Geographic Object-Based Image Analysis - Towards a new paradigm. ISPRS Journal of Photogrammetry and Remote Sensing, 87, 180-191. https://doi.org/10.1016/j.isprsjprs.2013.09.014

Bretz, K. (2017). Geospasial Indonesia: The Utilization of Spatial Data Through Geographic Information Systems Across Indonesia in Various Environmental Contexts. https://doi.org/10.13140/RG.2.2.18536.98565

Cooper, M. D. A., Evans, C. D., Zielinski, P., Levy, P. E., Gray, A., Peacock, M., ... Freeman, C. (2014). Infilled Ditches are Hotspots of Landscape Methane Flux Following Peatland Re-wetting. Ecosystems. https://doi.org/10.1007/s10021-0149791-3

Dohong, A., Aziz, A. A., \& Dargusch, P. (2017). A review of the drivers of tropical peatland degradation in South-East Asia. Land Use Policy, 69. https://doi.org/10.1016/j.landusepol.2017.09.035

Dronova, I. (2015). Object-based image analysis in wetland research: A review. Remote Sensing. https://doi.org/10.3390/rs70506380

Evers, S., Yule, C. M., Padfield, R., O’Reilly, P., \& Varkkey, H. (2017). Keep wetlands wet: the myth of sustainable development of tropical peatlands - implications for policies and management. Global Change Biology. https://doi.org/10.1111/gcb.13422

Gaveau, D. L. A., Salim, M. A., Hergoualc'H, K., Locatelli, B., Sloan, S., Wooster, M., ... Sheil, D. (2014). Major atmospheric emissions from peat fires in Southeast Asia during non-drought years: Evidence from the 2013 Sumatran fires. Scientific Reports. 
https://doi.org/10.1038/srep06112

Harrington, S., Teitelman, J., Rummel, E., Morse, B., Chen, P., Eisentraut, D., \& Mcdonough, D. (2017). Validating Google Earth Pro as a Scientific Utility for Use in Accident Reconstruction. https://doi.org/10.4271/2017-01-9750

Hirano, T., Kusin, K., Limin, S., \& Osaki, M. (2015). Evapotranspiration of tropical peat swamp forests. Global Change Biology. https://doi.org/10.1111/gcb.12653

Hu, Q., Wu, W., Xia, T., Yu, Q., Yang, P., Li, Z., \& Song, Q. (2013). Exploring the Use of Google Earth Imagery and Object-Based Methods in Land Use/Cover Mapping. Remote Sensing, 5(11), 6026-6042. https://doi.org/10.3390/rs5116026

Ishii, Y., Koizumi, K., Fukami, H., Yamamoto, K., Takahashi, H., Limin, S. H., ... Susilo, G. E. (2015). Groundwater in peatland. In Tropical Peatland Ecosystems. https://doi.org/10.1007/978-4-431-55681-7_17

Jaimes, A., \& Chang, S.-F. (2002). Concepts and Techniques for Indexing Visual Semantics. In Image Databases (pp. 497-565). Wiley-Blackwell. https://doi.org/10.1002/0471224634.ch17

Jauhiainen, J., Limin, S., Silvennoinen, H., \& Yasander, H. (2016). Carbon Dioxide and Methane Fluxes in Drained Tropical Peat before and after Hudrological Restoration Author ( s ): Jyrki Jauhiainen , Suwido Limin , Hanna Silvennoinen and Harri Vasander Published by: Wiley Stable URL: http://www.jstor.org/stable/276509, 89(12), 3503-3514.

Khodaskar, A., \& Ladhake, S. (2015). Semantic image analysis for intelligent image $\begin{array}{lllll}\text { retrieval. Procedia } & \text { Computer } & \text { Science, } & 48(\mathrm{C}), & 192-197 .\end{array}$ https://doi.org/10.1016/j.procs.2015.04.169

Koplitz, S. N., Mickley, L. J., Marlier, M. E., Buonocore, J. J., Kim, P. S., Liu, T., ... Myers, S. S. (2016). Public health impacts of the severe haze in Equatorial Asia in September-October 2015: demonstration of a new framework for informing fire management strategies to reduce downwind smoke exposure. Environmental Research Letters, 11(9), 094023. https://doi.org/10.1088/1748-9326/11/9/094023

Kristell Hergoualc'h, Rachel Carmenta, Stibniati Atmadja, Christopher Martius, Daniel Murdiyarso, \& Herry Purnomo. (2018). Managing peatlands in Indonesia Challenges and opportunities for local and global communities. CIFOR, 205. https://doi.org/10.17528/cifor/006449

Malarvizhi, K., Kumar, S. V., \& Porchelvan, P. (2016). Use of High Resolution Google Earth Satellite Imagery in Landuse Map Preparation for Urban Related Applications. Procedia Technology, 24, 1835-1842. https://doi.org/10.1016/j.protcy.2016.05.231

Ministry of Forestry, R. of I. Keputusan Menteri Kehutanan Republik Indonesia Nomor 733/menhut-II/2014 Tentang Kawasan Hutan dan Konservasi Perairan Provinsi Kalimantan Barat (2014). Indonesia.

Osaki, M., \& Tsuji, N. (2016). Tropical peatland ecosystems. Tropical Peatland Ecosystems. https://doi.org/10.1007/978-4-431-55681-7

Padfield, R., Waldron, S., Drew, S., Papargyrpoulou, E., Kumaran, S., Page, S., ... Tham, M. H. (2014). Research agendas for the sustainable management of tropical peatland in Malaysia. Environmental Conservation, (March), 1-11. https://doi.org/10.1017/S0376892914000034

Page, S. E., \& Baird, A. J. (2016). Peatlands and Global Change: Response and Resilience. Annual Review of Environment and Resources. https://doi.org/10.1146/annurevenviron-110615-085520

Page, S. E., Siegert, F., Rieley, J. O., Boehm, H.-D. V, Jaya, A., \& Limin, S. (2002). The 
amount of carbon released from peat and forest fires in Indonesia during 1997. Nature, 420(1), 61-65. https://doi.org/10.1038/nature01131

Rajbhandari, S., Aryal, J., Osborn, J., Musk, R., \& Lucieer, A. (2017). Benchmarking the Applicability of Ontology in Geographic Object-Based Image Analysis. ISPRS $\begin{array}{lllll}\text { International Journal of Geo-Information, } & 6(12), & 386 .\end{array}$ https://doi.org/10.3390/ijgi6120386

Rawlins, A., \& Morris, J. (2010). Social and economic aspects of peatland management in Northern Europe, with particular reference to the English case. Geoderma. https://doi.org/10.1016/j.geoderma.2009.02.022

Ritzema, H., Limin, S., Kusin, K., Jauhiainen, J., \& Wösten, H. (2014). Canal blocking strategies for hydrological restoration of degraded tropical peatlands in Central \begin{tabular}{llll}
\hline Kalimantan, & Indonesia. & Catena, & 114,
\end{tabular} https://doi.org/10.1016/j.catena.2013.10.009

Ritzema, H. P., Mutalib, A., Hassan, M., \& Moens, R. P. (1998). A new approach to water management of tropical peatlands: a case study from Malaysia. Irrigation and Drainage Systems, 12, 123-139.

Suryadiputra, N., Dohong, A., Waspodo, R., Lubis, I., Hasudungan, F., \& Wibisono, I. T. (2005). A Guide to Blocking of Canals and Ditches in Conjunction with the Community.

The President of Republic of Indonesia. Peraturam Pemerintah Republik Indonesia Nomor 57 Tahun 2016 Tentang Perubahan atas Peraturan Pemerintah Nomor 71 Tahun 2014 Tentang Perlindungan dan Pengelolaan Ekosistem Gambut (2016). Indonesia.

Van Kreveld, M. (2017). Geographic information systems. In Handbook of Discrete and Computational Geometry, Third Edition. https://doi.org/10.1201/9781315119601

Vonk, E. (2011). The Impact of Different Canal Configurations on the Drainage of Tropical Peatlands; A Geohydrological Model to Predict Drying of Sloping Peat Aquifers in Central Kalimantan, Indonesia. University of Twente.

Wijedasa, L. S., Jauhiainen, J., Könönen, M., Lampela, M., Vasander, H., Leblanc, M. C., ... Andersen, R. (2017). Denial of long-term issues with agriculture on tropical peatlands will have devastating consequences. Global Change Biology. https://doi.org/10.1111/gcb.13516

Yan, W., \& Galloway, W. (2017). Understanding Change Through the Lens of Resilience. In Rethinking Resilience, Adaptation and Transformation in a Time of Change. https://doi.org/10.1007/978-3-319-50171-0_1 